\title{
Pengaruh Latihan Fisik Terhadap Peningkatan Vo2Max Pemain Futsal STKIP BBG Banda Aceh
}

\author{
The Effect of Physical Training on the Increase of Vo2Max for Futsal Players \\ at STKIP BBG Banda Aceh
}

\author{
Munzir \\ Pendidikan Jasmani, STKIP Bina Bangsa Getsempena Banda Aceh, Alamat, Jl. Tanggul Kreung Aceh No. 34, \\ Rukoh Darussalam, Banda Aceh, 24161, Indonesia \\ e-mail: munzir@bbg.ac.id, irfandi@bbg.ac.id, zikrur@bbg.ac.id
}

\begin{abstract}
Abstrak
Penelitian ini bertujuan untuk mengetahui pengaruh fisik terhadap vo2max pada atlet futsal yang berjumlah samplenya adalah 8 orang. Teknik pengambilan sampel dilakukan dengan cara total sampling. Teknik pengumpulan data yang digunakan dalam penelitian ini adalah sebagai berikut: (1) latihan dilakukan dengan cara melakukan program yang efektif sejauh $2 \mathrm{~km}$ sampai dengan $5 \mathrm{~km}$ dengan tes awalannnya menggunakan vo2max pada atlet futsal Sekolah Tinggi Keguruan Dan Ilmu Pendidikan Bina Bangsa Getsempena Banda Aceh. Hasil penelitian yang diperoleh adalah terdapat pengaruh signifikan latihan fisik terhadap vo2max pada atlet futsal Sekolah Tinggi Keguruan Dan Ilmu Pendidikan Bina Bangsa Getsempena Banda Aceh. Hasil analisis diatas, diperoleh nilai t-hitung dari Vo2Max terhadap Vo2Max sebesar 3,33, sedangkan t-tabel dengan derajat kebebasan 8-2 $(\mathrm{dk}=6)$ pada taraf signifikasi $\alpha=0,05$ adalah sebesar 1,943 . Hal ini berati nilai t-hitung lebih besar dari nilai t-tabel. Dengan demikian dapat disimpulkan bahwa terdapat pengaruh yang signifikan antara Vo2Max terhadap Vo2Max pada pemain futsal Sekolah Tinggi Keguruan Dan Ilmu Pendidikaan Bina Bangsa Getsempena Banda Aceh.
\end{abstract}

Kata kunci: Latihan, VO2Max, futsal

\begin{abstract}
This study aims to determine the physical effect of Vmax in futsal athletes, with a total sample of 8 people. The sampling technique was done by total sampling. The data collection techniques used in this study were as follows: (1) training was carried out by means of total sampling. conduct an effective program as far as $2 \mathrm{~km}$ to $5 \mathrm{~km}$ with the initial test using vo2max on the futsal athletes of the Bina Bangsa College of Teacher Training and Education, Getsempena Banda Aceh. The results of the research obtained are that there is a significant effect of physical exercise on vo2max in the futsal athletes of the Teacher Training College And Education Science Bina Bangsa Getsempena Banda Aceh with an average value. The results of the above analysis showed that the T-count value of Vo2 Max to Vo2 Max was 3.33, while the T-table with degrees of freedom was 8-2 (dk $=6)$ at the level of the significance of $\alpha=0.05$ is 1.943. This means that the T-count value is greater than the T-table value. Thus, it can be concluded that there is a significant influence between Vo2Max and Vo2 Max on Futsal Players at the Getsempena National Development School, Banda Aceh.

Keywords: the drill V02Max, futsal
\end{abstract}

corresponding author: munzir@bbg.ac.id

Artikel Info:

Submitted: 07/03/2021

Revised : 25/03/2021

Accepted : 10/05/2021

Published: 16/05/2021

\section{(a) (1) DPENOAccess}

Journal Coaching Education Sports is licensed under a Creatives Commons Attribution 4.0 International License.

Copyright $($ C 2021 


\section{A. Pendahuluan}

Olahraga futsal adalah permainan bola seperti sepakbola yang terlahir dari ketidakmampuan orang-orang dalam membuat lapangan sepakbola (Kurniawan, 2017). Menurut (Idris et al., 2020) Futsal adalah permainan yang terdiri dari dua tim yang masing-masing tim terdiri dari lima orang. Tujuannya untuk masuk ke gawang lawan dengan cara memanipulasi bola dan kaki.

Dalam permainan ini tidak harus menggunakan lapangan yang luas, permainan ini dapat dilakukan dilapangan basket, lapangan voli. Tetapi permainan futsal ini sangat mirip dengan permainan sepakbola, meskipun dapat dimainkan dalam ruangan (Serrano et al., 2013).

Olahraga mempunyai peranan utama dalam perjuangan hidup dan memberikan pengalaman yang bernilai nyata (Pujianto et al., 2020). Tetapi olahraga tidak terlepas dari gerakan yang melibatkan berbagai struktur atau jaringan pada tubuh manusia misalnya sendi, otot, meniscus atau discus, dan kapsulologamenter (Yuliasari, 2013) Dalam melakukan aktivitas olahraga seseorang juga harus memiliki kondisi fisik yang baik sehingga mampu melakukan aktivitas olahraga yang dilakukannya tanpa mengalami kelelahan yang berlebihan, sebaliknya apabila seseorang memiliki kondisi fisik yang kurang baik apalagi buruk maka seseorang akan kesulitan dalam melakukan aktivitas olahraga tersebut sehingga menyebabkan kelelahan yang berlebihan (Widodo, 2018).

Berdasarkan evaluasi yang peneliti lakukan pada pemain futsal sekolah tinggi keguruan dan ilmu pendidikan Banda Aceh 2019, Pada beberapa pertandingan melawan tim lokal setempat penampilan atlet menurun. Kondisi ini terlihat pada saat pertandingan babak pertama (15 menit awal), penampilan pemain bagus, pemain terkontrol, permainan lawan dapat diimbangi, akan tetapi memasuki 15 menit lebih kurang, akhir babak kedua terlihat penampilan atlet dalam keadaan sangat menurun seperti shooting yang tidak akurat, passing yang kurang tepat, serta penguasaan bola yang menurun (kosentrasi menurun).

Dalam hal ini terdapat factor yang mempengruhi penampilan dalam pertandingan tersebut antara lain daya ledak kecepatan, kelincahan, daya tahan, kekuatan (Palmizal et al., 2020). Berdasarkan kejadian yang terjadi dilapangan tersebut peneliti menduga kondisi fisik (VO2Max) yang dimiliki oleh atlet belum sesuai dengan harapan yang diinginkan, apabila hal ini terus dibiarkan akan mempengaruhi 
pencapaian prestasi maksimal (Oktariana \& Hardiyono, 2020).

\section{B. Metode Penelitian}

Dalam studi eksperimental, pengobatan diberikan pada populasi tertentu. Menurut (Sugiyono, 2012) metode penelitian eksperimental adalah metode dimana pengaruh perlakuan tertentu dapat diperiksa pada objek yang akan diperiksa dalam kondisi terkendali (Sugiyono, 2012).

Metode yang digunakan dalam penelitian ini adalah metode kuantitatif dengan menggunakan rumus-rumus untuk pengolahan datanya. Investigasi harus menggunakan metode yang tepat yang dapat mengungkap masalah. Keberhasilan penelitian ilmiah tidak terlepas dari metode yang digunakan. Dalam penelitian ini, peneliti menggabungkan metode penelitian eksperimental dengan metode tes. Saya yakin mereka bisa memberikan gambaran tentang bukti-bukti hasil penelitian..

\section{Populasi}

Populasi adalah keseluruhan objek penelitian yang terdiri dari manusia., bendabenda, hewan, tumbuhan-tumbuhan, gejalagejala, nilai tes, atau peristiwa-peristiwa sebagai sumber data yang memiliki karakteristik tertentu dalam suatu penelitian". Berdasarkan kutipan tersebut maka yang menjadi populasi dalam penelitian ini adalah: Pemain Futsal STKIP BBG Banda Aceh Tahun 2019.

\section{Sampel}

Menurut (Sugiyono, 2012) "Sampel adalah sebagian dari jumlah dan karakteristik yang dimiliki oleh populasi tersebut". Sedangkan menurut (S Arikunto, 2006) "Penentuan pengambilan Sample sebagai berikut: Apabila kurang dari 100 lebih baik diambil semua hingga penelitiannya merupakan penelitian populasi. Jika jumlah subjeknya besar dapat diambil antara $10-15 \%$ atau $20-55 \%$ atau lebih tergantung sedikit banyaknya jumlah populasi. Penelitian ini menggunakan $100 \%$ sampel dari jumlah populasi yaitu: 8 pemain futsal dari STKIP BBG Banda Aceh. “Apabila subjek kurang dari seratus (100), lebih baik diambil semua. Jadi, sampel dalam penelitian ini adalah 8 pemain Futsal Sekolah Tinggi Keguruan dan Ilmu Pendidikan Bina Bangsa Getsempena Banda Aceh Tahun 2019. 


\begin{tabular}{|c|c|c|c|c|}
\hline No & $\begin{array}{c}\text { Nama } \\
\text { sampel }\end{array}$ & $\begin{array}{c}\text { Jenis } \\
\text { kelamin }\end{array}$ & Umur & NIM \\
\hline 1. & $\begin{array}{l}\text { Fahrul } \\
\text { Romi }\end{array}$ & LK & $\begin{array}{c}19 \\
\text { Tahun }\end{array}$ & 1911040053 \\
\hline 2. & $\begin{array}{l}\text { Juliantri } \\
\text { karido }\end{array}$ & LK & $\begin{array}{c}19 \\
\text { Tahun }\end{array}$ & 1911040079 \\
\hline 3. & Zufrizal & LK & $\begin{array}{c}18 \\
\text { Tahun }\end{array}$ & 1911040180 \\
\hline 4. & $\begin{array}{l}\text { Ilham } \\
\text { Afrijal } \\
\text { Putra }\end{array}$ & LK & $\begin{array}{c}19 \\
\text { Tahun }\end{array}$ & 1911040147 \\
\hline 5 . & $\begin{array}{l}\text { Moenti } \\
\text { irfan }\end{array}$ & LK & $\begin{array}{c}19 \\
\text { Tahun }\end{array}$ & 1911040060 \\
\hline 6. & $\begin{array}{l}\text { Mufti } \\
\text { Reza }\end{array}$ & LK & $\begin{array}{c}18 \\
\text { Tahun }\end{array}$ & 1911040173 \\
\hline 7. & $\begin{array}{l}\text { Himatur } \\
\text { Rizal }\end{array}$ & LK & $\begin{array}{c}18 \\
\text { tahun }\end{array}$ & 1911040158 \\
\hline 8. & $\begin{array}{l}\text { Rahmat } \\
\text { Zaqrani }\end{array}$ & LK & $\begin{array}{c}18 \\
\text { tahun } \\
\end{array}$ & 1911040068 \\
\hline
\end{tabular}

Sumber: UKM Futsal BBG

Dalam penelitian ini menggunakan dua variabel bebas dan satu variabel terikat $(\mathrm{X})$. Variabel bebas (Y) dalam penelitian ini ada dua variabel bebas yaitu:

1. Variabel bebas adalah yang mempengaruhi, yaitu latihan fisik (Y),

2. Variabel terikat adalah variabel yang dipengaruhi, yaitu VO2 MAX (X).

\section{Teknik Pengambilan Data}

\section{Menurut (Suharsimi Arikunto,}

2010), instrumen pengumpulan data adalah alat bantu yang dipilih dan digunakan oleh peneliti dalam kegiatannya mengumpulkan data agar kegiatan tersebut menjadi sistematis dan dipermudah olehnya. Menurut (Sugiyono, 2012) teknik pengumpulan data merupakan langkah yang paling strategis dalam penelitian, karena tujuan utama dari penelitian adalah mendapatkan data.

Peneliti menyimpulkan bahwa teknik pengambilan data adalah suatu teknik dalam mengumpulkan data penelitian, karena tujuan utama dalam penelitian adalah mendapatkan data.

\section{Instrumen Penelitian}

Menurut (Sugiyono, 2012), menyatakan bahwa instrumen penelitian adalah suatu alat yang digunakan mengukur fenomena alam maupun sosial yang diamati. Keberhasilan suatu penelitian banyak ditentukan oleh instrumen yang digunakan, sebab data yang diperoleh untuk menjawab pertanyaan penelitian dan menguji melalui instrumen tersebut. Instrumen yang digunakan dalam penelitian ini peneliti menggunakan tiga tahapan penelitian yaitu: Pretest (tes awal) tes VO2 MAX, treatment (perlakuan) Latihan Fisik berupa Fartlek dan posttest (tes akhir) tes VO2 MAX sama seperti tes awal, Adapun langkah-langkah yang dilakukan ialah sebagai berikut :

\section{Preetest (tes awal)}

Tes awal (pretest) yang dilakukan oleh peneliti yaitu dengan melihat dan memberikan penilian langsung VO2 MAX pemain Futsal STKIP BBG Banda Aceh. Peneliti melakukan penilaian (Tes Balke ) 
kepada setiap masing-masing atlet dalam mengukur kemampuan VO2 MAX yang mampu dilakukan oleh pemain Futsal STKIP Banda Aceh, dengan langkahlangkah sebagai berikut :

1) Peneliti menjumpai pemain Futsal UKM STKIP BBG Banda Aceh.

2) Peneliti menyiapkan instrument penelitian kepada Futsal Club STKIP BBG Banda Aceh.

3) Peneliti memberikan Tes penilaian VO2 MAX

\section{Treatment (Perlakuan)}

Perlakuan yang dilakukan meliputi penerapan ketrampilan latihan jasmani berupa tes Balke atau permainan kecepatan yang dikembangkan oleh Gosta Halmer, yaitu sistem latihan kekuatan yang berarti menciptakan, memulihkan atau memelihara kondisi fisik seseorang (Rusli, 2000) Fartlek biasanya dimulai dengan jogging, kemudian bergantian dengan sprint pendek dan intens, bergantian dengan lari jarak menengah dengan kecepatan yang cukup tinggi, lalu jogging dan sprint lainnya, dll. Sebelum pertandingan, Farttlek berlatih di level aerobik, di mana masih ada cukup oksigen untuk memenuhi kebutuhan kerja otot.

Latihan ini dapat meningkatkan keseimbangan antara olahraga dan konsumsi oksigen selama berolahraga. Olahraga ini dilakukan di lapangan atau di area dengan sedikit turbulensi: Anda dapat menempuh jarak 5 hingga 20 kilometer dengan langkah sedang tanpa perubahan mendadak. Di dalam dunia.

Berlari dengan kecepatan dan jarak yang berbeda. Latihan ini dapat mempercepat daya tahan organ pelari dan bagian tubuh lainnya, serta meningkatkan daya tahan tubuh. Latihan harus dilakukan di medan yang berbeda, yaitu pada jarak 10-12 km. Pengoperasian yang lambat disarankan. Namun demikian kecepatan lari harus ditingkatkan, dengan kecepatan sedang 200 sampai 600 meter, lari cepat 100 sampai 150 meter, lari cepat 25 sampai 50 meter, dan menanjak turun bukit 40 sampai 80 meter.Berlari dan alternatif semacam itu seringkali penuh dengan jalan raya..

1) Setiap atlet melakuan latihan fisik secara bersama.

\section{Postest (tes akhir)}

Kegiatan posttest dilakuan setelah peneliti menerapkan latihan fisik pada pemain Futsal STKIP BBG Banda Aceh, Adapun tahapannya sebagai berikut:

1. Peneliti menerapkan tes ulang $\mathrm{VO} 2$ MAX (Tes balk ) pemain Futsal UKM STKIP BBG Banda Aceh dengan menggunakan kriteria penilaian. 


\section{Keriteria Penilaian VO2 MAX}

1. Tes Balke 15 menit.

Ini adalah tes Balke selama 15 menit, menggunakan kata "aerobik" dalam tes Balke sebagai prosedur dan standar untuk menginterpretasikan hasil tes, berdasarkan prediksi langsung dari VO2 max.

Cara Melakukan

- Testi siap berdiri di belakang garis star

○ Begitu benderah star di kibaskan,pencatat waktu mengaktifkan stopwatch dan testi lari secepat mungkin selama 15 menit

- Jarak yang dapat di tempuh selama 15 menit di catat oleh petugas

- Peserta berlari selama mungkin sampai waktu menunjukkan 15 menit.

- Setelah 15 menit, stopwatch dimatikan dan pelari diminta berhenti di tempatnya.

○ Jika operasi penghentian dianggap tidak benar, itu akan mengukur berapa meter dapat diukur dalam 15 menit operasi.

Pencatatan hasil.

2. Alat yang digunakan

○ Lapangan

○ Stop wath

○ Alat tulis

○ dll
Tes Balke

V02 Max $=33,3+$ (tarak Tempuh -133$) \times 0,172$

15

Norma V02 max Tes Balke 15 Menit

\begin{tabular}{|ll|ll|}
\hline \multicolumn{2}{|c|}{ LAKI- LAKI } & \multicolumn{2}{c|}{ PEREMPUAN } \\
\hline Baik Sekali & $61.00-$ Keatas & Baik Sekali & $54.30-$ Keatas \\
Baik & $60.90-55.10$ & Baik & $54.20-49.30$ \\
Sedang & $55.00-49.20$ & Sedang & $49.20-44.20$ \\
Kurang & $49.10-43.30$ & Kurang & $44.10-39.20$ \\
Kurang Sekali & $43.20-$ Kebawah & Kurang Sekali & 39.10 - Kebawah \\
\hline
\end{tabular}

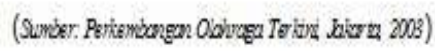

\section{Hasil dan Pembahasan}

Hasil serangkaian penelitian lapangan yang dilakukan oleh peneliti tentang pengaruh latihan fisik terhadap Peningkatan Vo2Max pada pemain futsal STKIP BBG Banda Aceh 2019, diperoleh data penelitian berupa data tes Vo2 Max. Tes yang diberikan untuk mengetahui pengaruh antara dua variabel tersebut. Data-data tersebut ditabulasikan ke dalam tabel dan hasilnya sebagai berikut.

Tabel 4.1 Hasil Pengukuran Latihan Fisik Terhadap Peningkatan Vo2 Max Pada Pemain Futsal Stkip BBG Banda Aceh 2019. 


\begin{tabular}{cccccc}
\hline \multirow{2}{*}{$\begin{array}{l}\text { N } \\
\text { o }\end{array}$} & Nama & \multicolumn{4}{c}{ VO2Max } \\
\cline { 3 - 6 } & & $\begin{array}{c}\text { Prete } \\
\boldsymbol{s}\end{array}$ & $\begin{array}{c}\text { Katego } \\
\boldsymbol{r i}\end{array}$ & $\begin{array}{c}\text { Poste } \\
\mathbf{s}\end{array}$ & Kategori \\
\hline 1 & MI & 50,12 & Sedang & 59,29 & Baik \\
\hline 2 & HR & 50,12 & Sedang & 54,7 & Sedang \\
\hline 3 & RZ & 59,28 & Baik & 63,88 & Sekali \\
\hline 4 & MR & 50,12 & Sedang & 59,88 & Baik \\
\hline 5 & FA & 59,28 & Baik & 63,88 & Sekali \\
\hline 6 & ZU & 54,7 & Sedang & 63,88 & Sekali \\
\hline 7 & JK & 54,7 & Sedang & 59,28 & Baik \\
\hline 8 & IA & 59,28 & Baik & 63,88 & Sekali \\
\hline & Jumlah & 437,6 & & 488,6 & \\
\hline
\end{tabular}

Dari hasil penelitian pada tabel diatas, maka dapat diketahui bahwa jumlah total nilai pada Pretes yaitu 437,6, pada Postes yaitu 488,67, pada Pemain Futsal STKIP Bina Bangsa Getsempena.

Berdasarkan hasil tes Vo2 Max, sebagaimana terdapat pada tabel di atas, kemudian data yang diperoleh dilanjutkan mencari nilai rata-rata sebagai berikut:

\section{Menghitung Nilai Rata-rata Pretest Vo2}

$\operatorname{Max}$

Berdasarkan hasil tes Vo2 Max Pemain Futsal Stkip BBG Banda Aceh 2019, sebagaimana terdapat pada tabel 4.1 di atas selanjutnya peneliti dapat menentukan nilai rata-rata adalah sebagai berikut:

$$
\bar{x}=\frac{\sum X}{N}
$$

$$
\begin{aligned}
& =\frac{437,6}{8} \\
& =54,7
\end{aligned}
$$

Berdasarkan hasil perhitungan di atas, dapat dikemukakan bahwa rata-rata Vo2 Max pada Pemain Futsal Stkip BBG 54,7 dengan kategori Sedang.

2. Menghitung Rata-rata Posttest Vo2 Max Berdasarkan hasil tes Vo2 Max atlet UKM sepakbola STKIP Bina Bangsa Getsempena Banda Aceh, sebagaimana terdapat pada tabel 4.1 di atas selanjutnya peneliti dapat menentukan nilai rata-rata adalah sebagai berikut:

$$
\begin{aligned}
\bar{x} & =\frac{\sum X}{N} \\
& =\frac{488,67}{8} \\
& =61,1
\end{aligned}
$$

Berdasarkan hasil perhitungan di atas, dapat dikemukakan bahwa rata-rata Postes pada Pemain Futsal STKIP BBG 61,1 dengan Kategori baik sekali.

\section{Perhitungan Nilai Standar Deviasi}

Selanjutnya untuk mencari standar deviasi berdasarkan hasil Pretes dan Postes sebagaimana terdapat pada tabel di bawah, selanjutnya dapat ditentukan standar deviasi sebagai berikut: 
Tabel 4.2 Hasil perkalian Nilai Pretes dan

Postes pada Pemain Futsal STKIP Bina

Bangsa Getsempena.

\begin{tabular}{cccc}
\hline No & Nama & $\begin{array}{c}\text { Pretes } \\
\text { X }\end{array}$ & $\begin{array}{c}\text { Poste } \\
\text { Y }\end{array}$ \\
\hline 1 & MF & 50,12 & 59,29 \\
\hline 2 & ZA & 50,12 & 54,7 \\
\hline 3 & IR & 59,28 & 63,88 \\
\hline 4 & DR & 50,12 & 59,88 \\
\hline 5 & RM & 59,28 & 63,88 \\
\hline 6 & BW & 54,7 & 63,88 \\
\hline 7 & DA & 54,7 & 59,28 \\
\hline 8 & AR & 59,28 & 63,88 \\
\hline Jumlah & 437,6 & 488,67 \\
\hline \multicolumn{1}{c}{} \\
Berdasarkan tabel di \\
nilai sebagai berikut: \\
X $=$ & 437,6 \\
Y $=$ & 488,67 \\
$X^{2}=$ & 24062,58 \\
$Y^{2}=$ & 29929,74 \\
X.Y $=$ & 26811,64
\end{tabular}

1. Mencari Standar Deviasi Nilai Pretest

Berdasarkan hasil tes nilai pretest sebagaimana terdapat pada tabel 4.2 di atas, selanjutnya dapat ditentukan standar deviasi dengan menggunakan rumus sebagai berikut:

$$
\begin{aligned}
\operatorname{SDX} & =\sqrt{\frac{N\left(\sum X^{2}\right)-\left(\sum X\right)^{2}}{N(N-1)}} \\
& =\sqrt{\frac{8(24062,58)-(437,6)^{2}}{8(8-1)}}
\end{aligned}
$$

$$
\begin{aligned}
& =\sqrt{\frac{192500,6-191493,8}{56}} \\
& =\sqrt{\frac{1006,867}{56}} \\
& =\sqrt{17,98} \\
& =4,2
\end{aligned}
$$

Dari perhitungan di atas diperoleh ar deviasi Pretes pada Pemain Futsal TKIP Bina Bangsa Getsempena Tahun 2019 sebesar 4,2.

2. Menghitung Standar Deviasi Posttest

Berdasarkan hasil tes nilai posttest sebagaimana terdapat pada tabel 4.2 di atas, selanjutnya dapat ditentukan standar deviasi dengan menggunakan rumus berikut:

$$
\begin{aligned}
\text { SDY } & =\sqrt{\frac{N\left(\sum Y^{2}\right)-\left(\sum Y\right)^{2}}{n(n-1)}} \\
& =\sqrt{\frac{8(29929,74)-(488,67)^{2}}{8(8-1)}} \\
& =\sqrt{\frac{239438-238798,4}{56}} \\
& =\sqrt{\frac{639,5871}{56}} \\
& =\sqrt{11.42} \\
& =3,4
\end{aligned}
$$

Berdasarkan perhitungan diatas maka standar deviasi hasil post test pemain futsal STKIP dari Getsempena tahun 2019 adalah 3.4. 


\section{Pengujian Hipotesis}

Untuk membuktikan hipotesis yang telah dirumuskan diterima atau ditolak kebenarannya, Penulis menggunakan rumus uji signifikansi sebagai berikut:

$$
\begin{aligned}
& t=\frac{x 1-x 2}{\sqrt{\frac{s 1^{2}}{n 1}+\frac{s 2^{2}}{n 1}}} \\
& t=\frac{54,7-61,1}{\sqrt{\frac{4,2^{2}}{8}+\frac{3,4^{2}}{8}}} \\
& t=\frac{6,4}{\sqrt{\frac{17,98}{8}+\frac{11,42}{8}}} \\
& t=\frac{6,4}{\sqrt{2,25+1,43}} \\
& t=\frac{6,4}{\sqrt{3,68}} \\
& t=\frac{6,4}{1,92} \\
& t=3,33
\end{aligned}
$$

Berdasarkan hasil analisis diatas, maka diperoleh nilai Pengaruh yang signifikan antara Latihan Fisik Terhadap Peningkatan Vo2 Max diperoleh bahwa nilai korelasi tersebut sebesar 3,33.

Hasil analisis sebelumnya menunjukkan bahwa, dibandingkan dengan Vo2 Max, nilai $\mathrm{T}$ counter Vo2Max adalah 3,33, sedangkan $\mathrm{T}$ tabel dengan derajat kebebasan 8-2 $(\mathrm{dk}=6)$ pada taraf signifikansi $\alpha=0,05$ adalah 1.943 .
Menunjukkan bahwa nilai t hitung lebih besar dari nilai $\mathrm{t}$ tabel. Dengan demikian dapat disimpulkan bahwa diantara pemain futsal STKIP Bina Bangsa Getsempena terdapat pengaruh yang signifikan antara Vo2Max.

\section{Pembahasan Penelitian}

Dalam teori latihan, disebutkan ada empat aspek latihan yang perlu diperhatikan dan dilatih secara seksama yaitu 1) latihan fisik, 2) latihan teknik, 3) latihan taktik, dan 4) latihan mental (Harsono, 2013). Perkembangan kondisi fisik yang menyeluruh amatlah penting, oleh karena tanpa kondisi fisik yang baik atlet tidak akan dapat mengikuti latihan-latihan dengan sempurna.

Kondisi fisik merupakan salah satu aspek latihan yang paling dasar untuk dilatih dan di tingkatkan, untuk mendapatkan kondisi fisik yang baik diperlukan persiapan latihan yang dapat meningkatkan dan mengembangkan kondisi fisik, daya tahan merupakan salah satu komponen fisik yang sangat penting untuk dilatih dan ditingkatkan menjadi stamina dalam upaya mencapai prestasi yang optimal (Kamadi, 2020).

VO2max adalah daya tahan Volume Oxygen Maximal yang ada pada pemain/ atlet tersebut (Prakoso \& Sugiyanto, 2017). 
Tujuan utama dari latihan daya tahan adalah meningkatkan kemampuan kerja jantung. Daya tahan adalah keadaan atau kondisi tubuh yang mampu berlatih untuk waktu yang lama, tanpa mengalami kelelahan yang berlebihan setelah menyelesaikan latihan tersebut (Ardiansyah \& Nasrullah, 2017). Menurut (Warni et al., 2017) daya tahan adalah kesanggupan bekerja dengan intensitas tertentu dalam rentang waktu yang cukup lama, tanpa kelelahan yang berlebihan". Sedangkan menurut (Prakoso \& Sugiyanto, 2017), “daya tahan adalah hasil kemampuan individu untuk memelihara gerakannya dalam kurun waktu tertentu”.

Dari hasil penelitian diketahui bahwa terdapat Pengaruh Vo2 Max terhadap Vo2 Max pada Pemain Futsal STKIP Bina Bangsa Getsempena. Hasil analisis di atas, diperoleh nilai t-hitung dari Vo2 Max terhadap Vo2 Max sebesar 3,33. Hasil analisis sebelumnya menunjukkan bahwa, dibandingkan dengan Vo2 Max, nilai T counter Vo2Max adalah 3,33, dan taraf signifikansi t-tabel dengan derajat kebebasan 8-2 (dk=6) adalah $\alpha=0,05$. Ini 1.943. Dengan demikian, dapat disimpulkan bahwa diantara pemain futsal STKIP Bina Bangsa Getsempena terdapat pengaruh yang signifikan antara Vo2Max dengan Vo2 Max.

\section{Kesimpulan}

Berdasarkan hasil penelitian yang telah diperoleh dengan pengolahan serta analisis data dari penelitian yang berjudul dengan pengaruh latihan fisik terhadap peningkatan Vo2MAX pemain futsal STKIP Bina Bangsa Getsempena, maka dapat diambil kesimpulan sebagai berikut: terdapat Pengaruh signifikan antara Vo2Max dengan Vo2Max, hal tersebut ditunjukkan oleh hasil uji hipotesis sebesar 3,33, pada Pemain Futsal STKIP Bina Bangsa Getsempena.

\section{Saran}

Berdasarkan kesimpulan penelitian di atas, ada beberapa saran yang dapat disampaikan, yaitu:

a. Bagi pelatih, hendaknya memperhatikan latihan Fisik pemain untuk mendapatkan daya tahan otot jantung atlet dan meningkatkan kapasitas prestasi atlet.

b. Dalam skripsi ini masih banyak kekurangan, untuk itu bagi peneliti selanjutnya hendaknya mengembangkan dan menyempurnakan instrument penelitian ini.

c. Bagi peneliti selanjutnya hendaknya menambah variabel lain.

\section{Bagi Pemain Futsal}

Daya tahan kardiorespirasi atau kapasitas Vo2Max merupakan salah satu 
unsur pokok atau hal yang sangat penting yang harus dimiliki oleh pemain futsal. Peningkatan kapasitas Vo2Max dapat dicapai dengan memberikan peningkatan intensitas latiha. Seorang pemain futsal hendaknyaselalu berupaya meningkatkan kapasitas Vo2Max dengan melakukan latihan-latihan yang sesuai dengan karakteristik pemain serta ketersediaan sarana dan prasarana.

\section{Bagi Peneliti Selanjutnya}

Hasil penelitian menunjukkan bahwa penngkatan intensitas latihan futsal terbukti berpengaruh terhadap peningkatan kapasitas Vo2Max pemain futsal. Peneliti yang akan datang dapat melakukan penelitian dengan menganti program berpengaruh latihan yang diberikan atau menambahkan faktor-faktor lain yang terhadap peningkatan kapasitas Vo2Max pemain futsal.

\section{Ucapan Terima Kasih}

Pada kesempatan kali ini saya turut mengucapkan rasa terimakasih yang sedalam - dalamnya terutama kepada, pelatih UKM Futsal BBG, Ketua program studi pendidikan jasmani dan semua unsur kalangan dosen yang senantiasa mensupport kegiatan tersebut.

\section{Daftar Pustaka}

Ardiansyah, M., \& Nasrullah, N. (2017).
Analisis Tingkat Daya Tahan Kardiorespirasi Wasit Sepakbola Di Palembang Tahun 2017. Jurnal Prestasi, 1(2), 35-40. https://doi.org/https://doi.org/10.24114/ jp.v1i2.8064

Arikunto, S. (2006). Data Penelitian Deskriptif. Management Penelitian Analisis.

Arikunto, Suharsimi. (2010). Prosedur Penelitian Suatu Pendekatan Praktik (edisi revisi 2010). In Jakarta: Rineka Cipta (10th ed.).

Harsono. (2013). Coaching dan AspekAspek Psikologi dalam Coaching. Dedikbud Dirjen Dikti.

Idris, F., Febi Kurniawan, \& Akhmad Dimyati. (2020). Pengembangan Model Latihan Passing Dan Movement Without The Ball Futsal Pada Kegiatan Ekstrakulikuler Sekolah Menengah Atas Berbasis Games Kompetisi. Journal Coaching Education Sports, 1(2), 71-82. https://doi.org/10.31599/jces.v1i2.330

Kamadi, L. (2020). Kontribusi Kondisi Fisik Terhadap Kemampuan Servis Bawah Dalam Permainan Bolavoli Contribution of Physical Conditions to Lower Service Ability in Volleyball Games. Journal Coaching Education Sports, 1(2), 151-160. https://doi.org/https://doi.org/10.31599/ jces.v1i2.369

Kurniawan, F. (2017). Efektivitas Model Latihan Passing Control Febi Futsal Games Terhadap Peningkatan Hasil Passing Control Olahraga Futsal Untuk Pemain Pemula. Motion: Jurnal Riset Physical Education, 8(2), 214-222. https://doi.org/https://doi.org/10.33558/ motion.v8i2.224

Oktariana, D., \& Hardiyono, B. (2020). Pengaruh Daya Ledak Otot Lengan, Daya Ledak Otot Tungkai Dan Kekuatan Otot Perut Terhadap Hasil 
Smash Bola Voli Pada Siswa SMK Negeri 3 Palembang. Journal Coaching Education Sports, 1(1), 13-24. https://doi.org/10.31599/jces.v1i1.82

Palmizal, A., Munar, H., Muchlisin, A., \& Pasaribu, N. (2020). Kemampuan Vo2max Atlet Sepakbola Ditinjau dari Latihan. Journal Coaching Education Sports, 1(1), 27-36. https://doi.org/10.31599/jces.v1i1.83

Prakoso, G. P. W., \& Sugiyanto, F. (2017). Pengaruh Metode Latihan dan Daya Tahan Otot Tungkai terhadap Hasil Peningkatan Kapasitas Vo 2 max Pemain Bola Basket. Jurnal Keolahragaan, 5(2), 151-160. https://doi.org/https://doi.org/10.21831/ jk.v5i2.10177

Pujianto, D., Sutisyana, A., Arwin, A., \& Nopiyanto, Y. E. (2020). Pengembangan Model Latihan Passing Sepakbola Berbasis Sasaran Teman. Journal Coaching Education Sports, 1(1), 1-12. https://doi.org/10.31599/jces.v1i1.81

Rusli, L. (2000). Asas-asas Pendidikan Jasmani Pendekatan Pendidikan Gerak di Sekolah Dasar. Depniknas. https://opac.ikippgriptk.ac.id/index.php $? \mathrm{p}=$ show_detail\&id $=3554$

Serrano, J., Shahidian, S., Sampaio, J., \& Leite, N. (2013). The importance of sports performance factors and training contents from the perspective of futsal coaches. Journal of Human Kinetics, 38 , 151-160. https://doi.org/10.2478/hukin-20130055

Sugiyono. (2012). Metode penelitian kuantitatif dan $R \& D$. Alfabeta.

Warni, H., Arifin, R., \& Bastian, R. A. (2017). Pengaruh Latihan Daya Tahan (Endurance) Terhadap Peningkatan Vo2max Pemain Sepakbola. Multilateral: Jurnal Pendidikan Jasmani Dan Olahraga, 16(2), 121-
126.

https://doi.org/http://dx.doi.org/10.2052 7/multilateral.v16i2.4248

Widodo, A. (2018). Makna Dan Peran Pendidikan Jasmani Dalam Pembentukan Insan. Jurnal Motion, 9(1), 53-60. https://www.researchgate.net/publicatio n/329442726_MAKNA_DAN_PERAN _PENDIDIKAN_JASMANI_DALAM _PEMBENTUKAN_INSAN_YANG_ MELEK JASMANIAHTERLITERASI_JASMANIAHNYA YULIASARI, A. (2013). PERAN DOMINAN MOTIVASI INTRINSIK DAN MOTIVASI EKSTRINSIK SISWA PUTRI DALAM MENGIKUTI KEGIATAN EKSTRAKURIKULER FUTSAL (Studi pada SMA Dr. Soetomo Surabaya). Jurnal Pendidikan Olahraga Dan Kesehatan. 